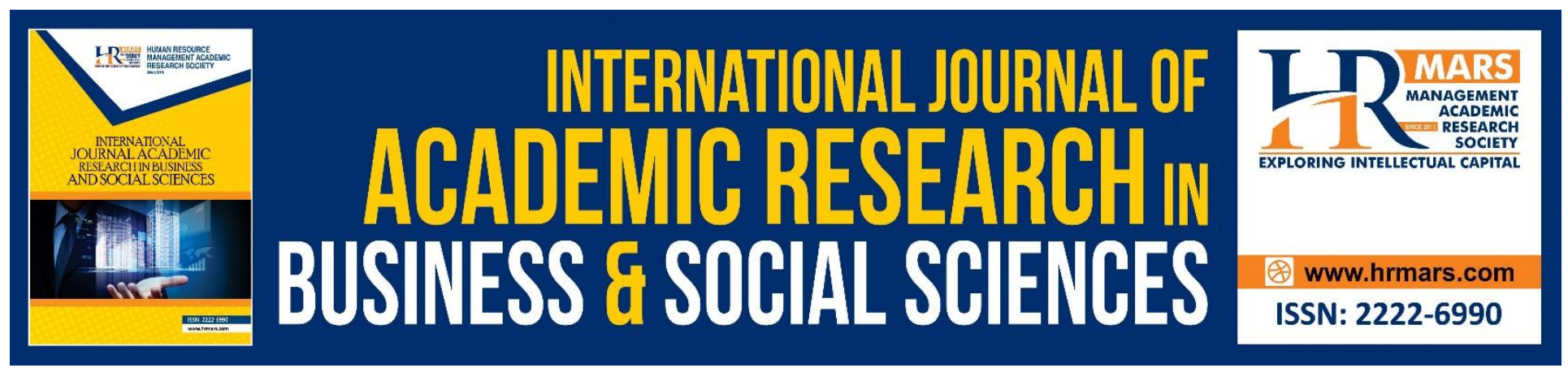

\title{
When You Don't have to be Sequential: A Meta-Analysis
}

\section{Ilda Salwani Binti Ameer Hamza, Abdul Halim Bin Abdullah, Sharifah Binti Osman}

To Link this Article: http://dx.doi.org/10.6007/IJARBSS/v9-i2/5671

DOI: $\quad 10.6007 /$ IJARBSS/v9-i2/5671

Received: 02 Feb 2019, Revised: 17 Feb 2019, Accepted: 30 Feb 2019

Published Online: 03 March 2019

In-Text Citation: (Hamza, Abdullah, \& Osman, 2019)

To Cite this Article: Hamza, I. S. B. A., Abdullah, A. H. Bin, \& Osman, S. B. (2019). When You Don't have to be Sequential: A Meta-Analysis. International Journal of Academic Research in Business and Social Sciences, 9(2), 1142-1157.

\section{Copyright: (C) 2019 The Author(s)}

Published by Human Resource Management Academic Research Society (www.hrmars.com)

This article is published under the Creative Commons Attribution (CC BY 4.0) license. Anyone may reproduce, distribute, translate and create derivative works of this article (for both commercial and non-commercial purposes), subject to full attribution to the original publication and authors. The full terms of this license may be seen

at: $\underline{\text { http://creativecommons.org/licences/by/4.0/legalcode }}$

\section{Vol. 9, No. 2, 2019, Pg. 1142 - 1157}

Full Terms \& Conditions of access and use can be found at http://hrmars.com/index.php/pages/detail/publication-ethics 


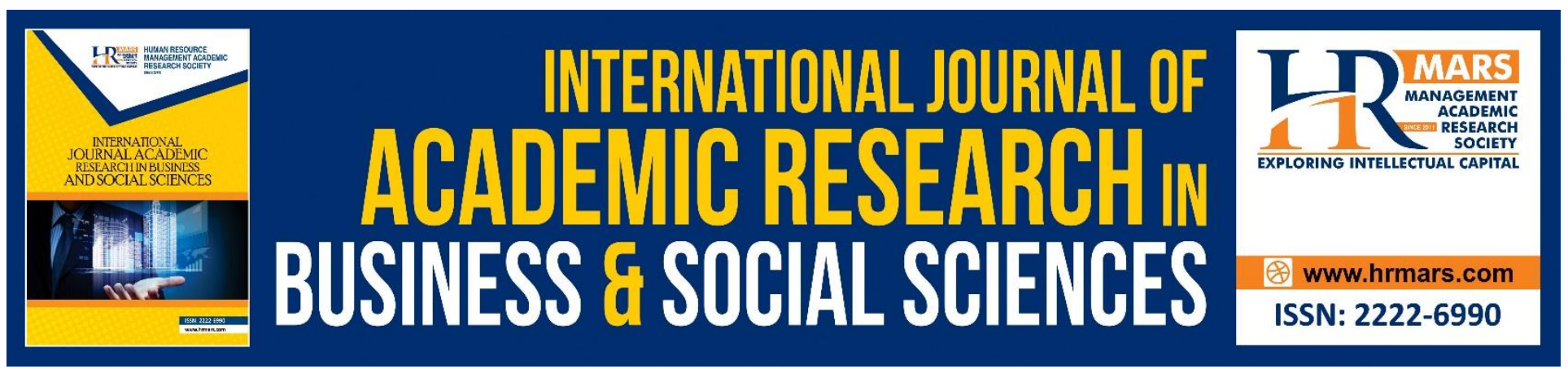

\title{
When You Don't have to be Sequential: A Meta-Analysis
}

\author{
Ilda Salwani Binti Ameer Hamza, Abdul Halim Bin Abdullah, \\ Sharifah Binti Osman \\ Technology University Malaysia, Malaysia
}

\begin{abstract}
Comparison approach is a cognitive process that is often used in a variety of domains specially to support effective mathematics learning. Students with low mathematical proficiency often make mistakes when solving a mathematical problem using different types of solving strategies. These mistakes can be prevented by presenting different strategies using the comparison approach in mathematics learning. If students are encouraged to compare, the similarities and differences become highlighted. This study examines the benefits of different types of comparison approaches in mathematics learning through a systematic review of research literature published between 2009 -2018, resulting in a total of 20 interventions (20 studies) that met the criteria for this study. The findings showed that students' conceptual knowledge, procedural knowledge, and procedural flexibility are related to the greater implementation of the intervention, which when used sufficiently, can improve long-term mathematics learning. This study suggests that teachers may need additional support in preparing mathematics instruction using the comparison approach and that knowing the benefits of different types of comparisons in mathematics learning may persuade and help them to decide what to compare and when to use comparisons.
\end{abstract}

Keywords: Comparison Approach, Mathematics Instruction, Intervention, Mathematics Learning.

\section{Introduction}

Comparing approach supports learning in children and adults across a variety of domains including mathematics (Ganor-Stern \& Steinhorn, 2018; Abreu_Mendoza \& Arias-Trejo, 2015; AbreuMendoza, Soto-Alba \& Arias-Trejo, 2013; Lemaire \& Lechacheur, 2011). Identifying similarities and differences in multiple strategies is the basic path of flexible change in knowledge among students. However, flexible change in mathematics knowledge might be possible if students have some prior knowledge of one of the strategies in order to transfer and engage with mathematics (Star, Rittle- 
Johnson, Durkin, 2016; Ziegler \& Stern, 2016; Star \& Rittle-Johnson, 2009; Rittle-Johnson, Star \& Durkin, 2009).

Previous research has found that when students are familiar with one strategy, they can learn a new strategy via analogy to recall the familiar one (Rittle, Star \& Durkin, 2009). Comparison influences classroom instruction by drawing connections through relational comparisons to improve long-term learning ability among students (Ziegler \& Stern, 2016; Ziegler \& Stern, 2014; Richland, Stigler \& Holyoak, 2012; Clarke \& Roche, 2009). In other words, students who constantly learn through comparison will experience enhanced mathematical competence in procedural knowledge, procedural flexibility and conceptual knowledge (Durkin, Star \& Rittle, 2017; Ziegler \& Stern, 2014, Lemaire \& Lechachure, 2011; Clarke \& Roche, 2009).

However, many teachers are not open to multiple solutions using the comparison approach due to over reliance on the sequential approach (Bingolbali, 2011; Rittle-Johnson, Star \& Durkin, 2009). They are also unaware of effective instructional strategies (Abdul Rahman, Syed Zamri \& Leong, 2018; Bingolbali, 2011; Hattikudur \& Alibali, 2010). There are major challenges faced by teachers in finding appropriate instructional strategies that have a positive impact on students' learning (Fazio, DeWolf \& Siegler, 2015; Ziegler \& Stern, 2014). This meta-analysis attempts to determine the effective strategies in mathematics learning at kindergarten, primary school, high school and tertiary level.

\section{Research Questions}

This meta-analysis is a structured methodology aimed at synthesizing the existing studies for future improvement of the comparison approach. This study is aimed at establishing an overview of dominant types of comparison approaches at different school levels. Apart from that, this study also investigated the benefits of comparison approach in mathematics learning. Explicitly, this paper attempts to answer the research questions below:

i. What are the dominant types of comparison approaches in mathematics learning?

ii. What are the benefits of comparison approach in mathematics learning?

\section{Methodology}

This study used the meta-analysis design where studies related to comparison approach were analyzed systematically. In particular, meta-analysis is an analysis upon other analysis, involving the merger of research findings that are comparable and to be taken into account in determining the core effect (Cohen, Manion, \& Morrison, 2011). This study followed the procedures outlined by Webster \& Watson (2002) which were adapted for the purpose of choosing related articles for the study. Several databases subscribed by the University Library such as Science Direct, Wiley Online Library, Taylor \& Francis Online and Web of Science were used to find the related articles. Additionally, search engines such as Google Scholar and Google Search were also used in the study. Articles related to the comparison approach in mathematics learning that were published between 2009 through 2018 were downloaded and analyzed. The search was performed using specific keywords namely: "comparison in mathematics", "comparison in mathematic strategies", "comparison in mathematics instruction", "magnitude comparison in mathematics", "numerical comparison in mathematics", and "fraction comparison strategies". The first essential 
INTERNATIONAL JOURNAL OF ACADEMIC RESEARCH IN BUSINESS AND SOCIAL SCIENCES Vol. 9, No. 2, Feb, 2019, E-ISSN: 2222-6990 C 2019 HRMARS

criterion for choosing an article was that it must be a study in mathematics education using the comparison approach in mathematics learning. The second criterion is that the types of samples were from different levels of education. As a result, a total of 20 studies that satisfied all the criteria were reviewed in this study, as shown in Table 1.

Table 1: List of Studies Related to Comparison Approach in Mathematics Learning

\begin{tabular}{|c|c|c|c|}
\hline Studies & $\begin{array}{l}\text { Level of } \\
\text { Education }\end{array}$ & $\begin{array}{l}\text { Sample } \\
\text { Size }\end{array}$ & Journal \\
\hline Ganor-Stern \& Steinhorn (2018) & $\begin{array}{l}\text { Tertiary } \\
\text { Education }\end{array}$ & 17 & Acta Psychologica \\
\hline Xenidou-Dervou et al. (2017) & $\begin{array}{c}\text { Kindergarten } \\
\text { and Primary } \\
\text { School }\end{array}$ & $\begin{array}{l}326 \\
(Y 1) \\
(Y 2)\end{array}$ & $\begin{array}{l}\text { Learning and } \\
\text { Instruction }\end{array}$ \\
\hline Ziegler \& Stern (2016) & Primary School & $98(Y 6)$ & $\begin{array}{l}\text { Learning and } \\
\text { Instruction }\end{array}$ \\
\hline Tavakoli (2016) & Primary School & $113(\mathrm{Y} 2)$ & $\begin{array}{l}\text { Europe's Journal of } \\
\text { Psychology }\end{array}$ \\
\hline $\begin{array}{l}\text { Hattikudur, Sidney, Alibali } \\
\text { (2016) }\end{array}$ & $\begin{array}{l}\text { Tertiary } \\
\text { Education }\end{array}$ & 112 & $\begin{array}{l}\text { Journal of Problem } \\
\text { Solving }\end{array}$ \\
\hline Ganor-Stern (2015) & $\begin{array}{c}\text { Tertiary } \\
\text { Education }\end{array}$ & 62 & Acta Psychologica \\
\hline Fazio, DeWolf \& Siegler (2015) & $\begin{array}{l}\text { Tertiary } \\
\text { Education }\end{array}$ & 64 & $\begin{array}{c}\text { Journal of } \\
\text { Experimental } \\
\text { Psychology }\end{array}$ \\
\hline Linsen et al. (2015) & Primary School & $51(Y 4)$ & $\begin{array}{l}\text { Learning and } \\
\text { Instruction }\end{array}$ \\
\hline Ganor-Stern \& Weiss (2015) & $\begin{array}{c}\text { Tertiary } \\
\text { Education }\end{array}$ & 42 & Psychological Research \\
\hline $\begin{array}{l}\text { Abreu-Mendoza \& Arias-Trejo } \\
\text { (2015) }\end{array}$ & $\begin{array}{c}\text { Special } \\
\text { Education }\end{array}$ & 48 & $\begin{array}{c}\text { Research in } \\
\text { Developmental } \\
\text { Disabilities }\end{array}$ \\
\hline Ziegler \& Stern (2014) & Primary School & $226(Y 6)$ & $\begin{array}{l}\text { Learning and } \\
\text { Instruction }\end{array}$ \\
\hline $\begin{array}{l}\text { Abreu-Mendoza, Soto-Alba \& } \\
\text { Arias-Trejo (2013) }\end{array}$ & Kindergarten & 77 & Frontiers in Psychology \\
\hline Sasanguie \& Reynvoet ( 2013) & Primary School & $\begin{array}{l}28(\mathrm{Y} 1) \\
29(\mathrm{Y} 2) \\
30(\mathrm{Y} 3)\end{array}$ & Psychologica Belgica \\
\hline Lemaire \& Lecacheur (2011) & $\begin{array}{c}\text { Primary School } \\
\text { and Secondary } \\
\text { School }\end{array}$ & $\begin{array}{l}39(\mathrm{Y} 7) \\
36(\mathrm{Y} 4) \\
31(\mathrm{Y3})\end{array}$ & Cognitive Development \\
\hline
\end{tabular}


INTERNATIONAL JOURNAL OF ACADEMIC RESEARCH IN BUSINESS AND SOCIAL SCIENCES Vol. 9, No. 2, Feb, 2019, E-ISSN: $2222-6990$ ๑ 2019 HRMARS

\begin{tabular}{|c|c|c|c|}
\hline Star et al. (2010) & Primary School & $\begin{array}{c}157 \text { (Y5 \& } \\
\text { Y6) }\end{array}$ & $\begin{array}{l}\text { Teaching Children } \\
\text { Mathematics }\end{array}$ \\
\hline $\begin{array}{l}\text { De Smedt, Verschaffel \& } \\
\text { Ghesquiere ( 2009) }\end{array}$ & Primary School & $47(Y 1)$ & $\begin{array}{c}\text { Journal of } \\
\text { Experimental Child } \\
\text { Psychology }\end{array}$ \\
\hline Star \& Rittle-Johnson (2009) & Primary School & $\begin{array}{l}69(Y 5) \\
88(Y 6)\end{array}$ & $\begin{array}{c}\text { Journal of } \\
\text { Experimental Child } \\
\text { Psychology }\end{array}$ \\
\hline $\begin{array}{l}\text { Rittle-Johnson, Star \& Durkin } \\
\text { (2009) }\end{array}$ & $\begin{array}{l}\text { Secondary } \\
\text { School }\end{array}$ & $\begin{array}{r}45(Y 7) \\
191(Y 8) \\
\end{array}$ & $\begin{array}{c}\text { Journal of Education } \\
\text { Psychology }\end{array}$ \\
\hline Star et al. (2009) & Primary School & $\begin{array}{c}65(\mathrm{Y} 5) \\
147(\mathrm{Y} 5 \& \\
\text { Y6) }\end{array}$ & $\begin{array}{c}\text { ZDM - The } \\
\text { International Journal } \\
\text { on } \\
\text { Mathematics } \\
\text { Education }\end{array}$ \\
\hline Clarke \& Roche (2009) & Primary School & $323(Y 6)$ & $\begin{array}{c}\text { Educational Studies in } \\
\text { Mathematics }\end{array}$ \\
\hline
\end{tabular}

\section{Findings and Discussion}

The research findings are divided into two parts. The first part discusses the dominant types of comparison approaches in mathematics learning using the sample profile to determine the different school levels in mathematics learning that are used in the comparison task. The second part discusses the benefits of comparison approach in mathematics learning.

\section{Types of Comparison Approaches in Mathematics Learning}

RQ 1: What are the dominant types of comparison approach in Mathematics Learning?

Based on the critical analysis on the objective and the research questions, there is only one research theme from previous researches that is relevant to the analysis i.e. the types of comparison approaches followed by the different school levels and comparisons in mathematic learning. 
INTERNATIONAL JOURNAL OF ACADEMIC RESEARCH IN BUSINESS AND SOCIAL SCIENCES Vol. 9, No. 2, Feb, 2019, E-ISSN: 2222-6990 C 2019 HRMARS

Table 2: Research Findings Related to the Dominant Types of Comparison Approaches in Mathematics Learning

\begin{tabular}{|c|c|c|}
\hline Research Themes & $f$ & Studies (Year) \\
\hline Number Comparison & 7 & $\begin{array}{l}\text { Xenidou-Dervou et al. (2017); Tavakoli } \\
\text { (2016); *Abreu-Mendoza \& Arias-Trejo } \\
\text { (2015); Linsen et al. (2015); Sasanguie \& } \\
\text { Reynvoet ( 2013); *Abreu-Mendoza, Soto- } \\
\text { Alba \& Arias-Trejo (2013); De Smedt, } \\
\text { Verschaffel \& Ghesquiere ( 2009) }\end{array}$ \\
\hline $\begin{array}{l}\text { Varieties of Strategy } \\
\text { comparison in solving the } \\
\text { same question }\end{array}$ & 6 & $\begin{array}{l}\text { Hattikudur, Sidney, Alibali, 2016; Lemaire } \\
\text { \& Lecacheur (2011); Star et al. (2010); } \\
\text { *Rittle-Johnson, Star \& Durkin (2009); Star } \\
\text { et al. (2009); Star \& Rittle-Johnson (2009) }\end{array}$ \\
\hline $\begin{array}{l}\text { Varieties of Solution } \\
\text { comparison in solving the } \\
\text { same question }\end{array}$ & 2 & $\begin{array}{l}\text { Ganor-Stern \& Steinhorn (2018); Ganor- } \\
\text { Stern (2015) }\end{array}$ \\
\hline $\begin{array}{l}\text { Solution Strategy comparison } \\
\text { in a variety of mathematic } \\
\text { operations }\end{array}$ & 2 & $\begin{array}{l}\text { Ziegler \& Stern (2016); Ziegler \& Stern } \\
\text { (2014) }\end{array}$ \\
\hline Fraction comparison & 2 & $\begin{array}{l}\text { Fazio, DeWolf \& Siegler (2015); Clarke \& } \\
\text { Roche (2009) }\end{array}$ \\
\hline Area comparison & 2 & $\begin{array}{l}\text { *Abreu-Mendoza \& Arias-Trejo (2015); } \\
\text { *Abreu-Mendoza, Soto-Alba \& Arias-Trejo } \\
\text { (2013) }\end{array}$ \\
\hline $\begin{array}{l}\text { Types of different question } \\
\text { comparisons with the same } \\
\text { solution }\end{array}$ & 1 & *Rittle-Johnson, Star \& Durkin (2009) \\
\hline
\end{tabular}

*Research that used two types of comparison tasks

Based on the analysis that had been carried out, it was found that most studies connected to comparative approaches are categorized under the number comparison theme. There are seven studies conducted under this theme. The number comparable theme can be classified into two parts i.e. number comparisons and comparisons of quantities of object groups. There are four studies under comparison of numbers and three studies under comparison of quantities of object groups. Additionally, there are five studies that fall under the theme of comparing various solutions strategies in the same question. Meanwhile, there are two studies each under the themes of comparison of various answer solutions in the same question, comparison of the solution strategy in distinct mathematical operations, and comparison of fractions. There is only one study under the theme of comparison of different types of questions with the same solution method. This finding reflects the broad gap that exists in the study of comparative types in mathematical learning. 
INTERNATIONAL JOURNAL OF ACADEMIC RESEARCH IN BUSINESS AND SOCIAL SCIENCES

Vol. 9, No. 2, Feb, 2019, E-ISSN: 2222-6990 C 2019 HRMARS

The Research Sample Profile in Mathematics Learning

After analyzing the sample profile of the previous study on comparative approaches in mathematical learning, five sample categories were determined namely pre-school students, special education, primary schools, secondary schools and tertiary education.

\begin{tabular}{|c|c|c|c|}
\hline Sample & $\begin{array}{l}\text { School } \\
\text { Levels }\end{array}$ & $\mathbf{F}$ & Studies (Years) \\
\hline Child & Pre-school & 2 & $\begin{array}{l}\text { *Xenidou-Dervou et al. (2017); Abreu- } \\
\text { Mendoza, Soto-Alba \& Arias-Trejo (2013) }\end{array}$ \\
\hline $\begin{array}{l}\text { Special } \\
\text { needs Child }\end{array}$ & $\begin{array}{c}\text { Special } \\
\text { Education }\end{array}$ & 1 & Abreu-Mendoza \& Arias-Trejo (2015) \\
\hline Child & Primary & 12 & $\begin{array}{l}\text { *Xenidou-Dervou et al. (2017); Ziegler \& Stern } \\
\text { (2016); Tavakoli (2016); Linsen et al. (2015); } \\
\text { Ziegler \& Stern (2014); Sasanguie \& Reynvoet ( } \\
\text { 2013); *Lemaire \& Lecacheur (2011); Star et al. } \\
\text { (2010); De Smedt, Verschaffel \& Ghesquiere } \\
\text { (2009); Star \& Rittle-Johnson (2009); Star et al. } \\
\text { (2009); Clarke \& Roche (2009) }\end{array}$ \\
\hline Teenager & Secondary & 2 & $\begin{array}{l}\text { *Lemaire \& Lecacheur (2011); Rittle-Johnson, } \\
\text { Star \& Durkin (2009) }\end{array}$ \\
\hline Young & Tertiary & 5 & $\begin{array}{l}\text { Ganor-Stern \& Steinhorn (2018); Hattikudur, } \\
\text { Sidney \& Alibali, 2016; Ganor-Stern \& Weiss } \\
\text { (2015); Ganor-Stern (2015); Fazio, DeWolf \& } \\
\text { Siegler (2015) }\end{array}$ \\
\hline
\end{tabular}

* The study has a different sample profile of education level

Based on the analysis completed, most previous studies related to the comparative approach in mathematical learning were conducted among primary school children. Ergo, there are many studies that focus on primary school children. This situation definitely reflects that there is a compelling gap in the study of comparative approaches in the context of pre-school education, special education, secondary education and tertiary education.

RQ 2: What are the benefits of comparison approach in mathematics learning?

The main research findings related to the benefit of comparison approach in mathematics according to the research objectives are as presented in Table 4. 
INTERNATIONAL JOURNAL OF ACADEMIC RESEARCH IN BUSINESS AND SOCIAL SCIENCES

Vol. 9, No. 2, Feb, 2019, E-ISSN: $2222-6990$ ๑ 2019 HRMARS

Table 4: Research Findings Related to the Benefit of Comparison Approach in Mathematics Learning

\begin{tabular}{|c|c|c|}
\hline Studies & Research Objective & Research Findings \\
\hline $\begin{array}{l}\text { Ganor-Stern \& } \\
\text { Steinhorn } \\
(2018)\end{array}$ & $\begin{array}{l}\text { To explore the estimation } \\
\text { skills and exact calculation } \\
\text { task of adults with ADHD in } \\
\text { comparison to typically } \\
\text { developing individuals } \\
\text { (ordinary adults). } \\
\text { To explore participant's } \\
\text { performance in both tasks } \\
\text { using measures of accuracy } \\
\text { and speed. } \\
\text { To analyze the strategy } \\
\text { used for the estimation } \\
\text { task. }\end{array}$ & $\begin{array}{l}\text { Adults with ADHD were slower in both tasks, but } \\
\text { not less accurate compared to the control group } \\
\text { (ordinary adults) } \\
\text { They were similar in showing enhanced } \\
\text { accuracy and speed for smaller and farther } \\
\text { problem sizes. } \\
\text { They differ in strategy execution, mainly of the } \\
\text { approximated calculation strategy, which } \\
\text { requires working memory resources. The } \\
\text { participants with ADHD was weak in the } \\
\text { calculation process in the estimation task that } \\
\text { relied on working memory, but that did not } \\
\text { hamper their estimation skills that are based on } \\
\text { sense of magnitude. }\end{array}$ \\
\hline $\begin{array}{l}\text { Xenidou-Dervou } \\
\text { et al. (2017) }\end{array}$ & $\begin{array}{l}\text { To investigate the } \\
\text { developmental roles of } \\
\text { non-symbolic (e.g., dot } \\
\text { arrays) and symbolic (i.e., } \\
\text { Arabic numerals) } \\
\text { magnitude comparison } \\
\text { skills, play in children's } \\
\text { mathematics learning }\end{array}$ & $\begin{array}{l}\text { The results demonstrated that symbolic and } \\
\text { non-symbolic comparison had different } \\
\text { developmental trajectories; symbolic } \\
\text { comparison underwent larger developmental } \\
\text { improvements. Both skills were longitudinal } \\
\text { predictors of children's future mathematical } \\
\text { achievement above and beyond IQ and WM. } \\
\text { Non-symbolic comparison was moderately } \\
\text { predictive only in kindergarten. Symbolic } \\
\text { comparison, however, was a robust and } \\
\text { consistent predictor of future mathematics } \\
\text { across all three years. It was a stronger predictor } \\
\text { compared to non-symbolic, and its predictive } \\
\text { power at the early stages was even comparable } \\
\text { to that of IQ. }\end{array}$ \\
\hline $\begin{array}{l}\text { Ziegler \& Stern } \\
(2016)\end{array}$ & $\begin{array}{l}\text { To investigate the } \\
\text { contrasting cases under } \\
\text { direct instruction leading } \\
\text { to better performance in } \\
\text { solving algebra problems } \\
\text { than sequential learning. }\end{array}$ & $\begin{array}{l}\text { The contrast learners clearly outperformed the } \\
\text { sequential learners in differentiating } \\
\text { superficially similar algebraic concepts on three } \\
\text { follow-up measures. } \\
\text { The benefits of contrasted comparison only } \\
\text { appeared with delay. }\end{array}$ \\
\hline
\end{tabular}


INTERNATIONAL JOURNAL OF ACADEMIC RESEARCH IN BUSINESS AND SOCIAL SCIENCES Vol. 9, No. 2, Feb, 2019, E-ISSN: 222 2-6990 @ 2019 HRMARS

\begin{tabular}{|c|c|c|}
\hline & $\begin{array}{l}\text { To investigate the } \\
\text { disadvantage of the } \\
\text { contrast group with } \\
\text { respect to immediate } \\
\text { learning measures which } \\
\text { also occur under direct } \\
\text { instruction. }\end{array}$ & $\begin{array}{l}\text { This indicates that contrast learning improves } \\
\text { long term memorization among year six } \\
\text { students. }\end{array}$ \\
\hline Tavakoli (2016) & $\begin{array}{l}\text { To investigate this } \\
\text { relationship among second } \\
\text { grade Iranian children } \\
\text { using a pre-established } \\
\text { test (known as the } \\
\text { Numeracy Screener) to } \\
\text { measure numerical } \\
\text { magnitude comparison } \\
\text { accuracy. }\end{array}$ & $\begin{array}{l}\text { The results revealed that both the symbolic and } \\
\text { non-symbolic items of the Numeracy Screener } \\
\text { significantly correlated with arithmetic ability. } \\
\text { However, after controlling for the effect of } \\
\text { working memory, processing speed, and long- } \\
\text { term memory, only the performance on } \\
\text { symbolic items accounted for the unique } \\
\text { variances in the children's arithmetic ability. } \\
\text { Furthermore, while } \\
\text { working memory uniquely contributed to } \\
\text { arithmetic ability in one- and two-digit } \\
\text { arithmetic problem solving, processing speed } \\
\text { uniquely explained that } \\
\text { only the variance in single-digit arithmetic skills } \\
\text { and long-term memory did not contribute to } \\
\text { any significant additional variance for one-digit } \\
\text { or } \\
\text { two-digit arithmetic problem solving. }\end{array}$ \\
\hline $\begin{array}{l}\text { Ganor-Stern } \\
\text { (2015) }\end{array}$ & $\begin{array}{lr}\text { To } & \text { investigate } \\
\text { computational } & \text { estimation } \\
\text { skills of } & \text { multi-digit } \\
\text { multiplication } & \text { problems } \\
\text { using an estimation } \\
\text { comparison task among } \\
\text { college students. }\end{array}$ & $\begin{array}{l}\text { The participants showed enhanced accuracy } \\
\text { and speed for smaller and farther problem sizes. } \\
\text { Moreover, approximate calculation and sense of } \\
\text { magnitude were the strategies used to solve the } \\
\text { task. } \\
\text { The strategy choice was influenced by the } \\
\text { distance between the reference number and } \\
\text { exact answer and by the interaction of problem } \\
\text { size and reference number size. }\end{array}$ \\
\hline $\begin{array}{l}\text { Fazio, DeWolf \& } \\
\text { Siegler (2015) }\end{array}$ & $\begin{array}{l}\text { To examine on a trial-by- } \\
\text { trial basis the fraction } \\
\text { magnitude comparison } \\
\text { strategies of adults } \\
\text { with more and less } \\
\text { mathematical knowledge }\end{array}$ & $\begin{array}{l}\text { The findings showed that college students with } \\
\text { high mathematical proficiency used a variety of } \\
\text { strategies that yielded to correct performance } \\
\text { if executed correctly. } \\
\text { Students with less mathematical proficiency } \\
\text { sometimes used strategies similar to those }\end{array}$ \\
\hline
\end{tabular}




\begin{tabular}{|c|c|c|}
\hline & & $\begin{array}{l}\text { used by the mathematically proficient students, } \\
\text { but often used flawed strategies that yielded to } \\
\text { inaccurate performance because of lack of } \\
\text { conceptual understanding, rather than } \\
\text { difficulty recalling such strategies. } \\
\text { Therefore, the increases in accuracy and speed } \\
\text { were related to differences in strategy use, } \\
\text { strategy choice, and strategy execution. }\end{array}$ \\
\hline $\begin{array}{l}\text { Linsen et al. } \\
(2015)\end{array}$ & $\begin{array}{l}\text { To examine how numerical } \\
\text { magnitude processing is } \\
\text { associated with mental and } \\
\text { algorithmic computation, } \\
\text { and whether this } \\
\text { association with numerical } \\
\text { magnitude processing is } \\
\text { different for mental versus } \\
\text { algorithmic computation. } \\
\text { To examine the possibility } \\
\text { that associations between } \\
\text { numerical magnitude } \\
\text { processing and multi-digit } \\
\text { subtraction could be } \\
\text { explained by elementary } \\
\text { arithmetic fact knowledge. }\end{array}$ & $\begin{array}{l}\text { The findings showed that both calculation } \\
\text { methods rely on numerical magnitude } \\
\text { processing. However, mental computation is } \\
\text { more strongly associated with numerical } \\
\text { magnitude processing, which is considered as a } \\
\text { basic number sense than algorithmic } \\
\text { computation. } \\
\text { Elementary arithmetic fact knowledge was also } \\
\text { significantly correlated with both the speed and } \\
\text { accuracy by which children solve multi-digit } \\
\text { subtraction items. } \\
\text { Results indicated that both symbolic and non- } \\
\text { symbolic numerical magnitude comparison } \\
\text { accuracy predicted a significant amount of } \\
\text { variance in children's accuracy on mental } \\
\text { calculation, whereas elementary arithmetic fact } \\
\text { knowledge did not. }\end{array}$ \\
\hline $\begin{array}{l}\text { Ganor-Stern } \quad \& \\
\text { Weiss (2015) }\end{array}$ & $\begin{array}{l}\text { To investigate college } \\
\text { students' ability to } \\
\text { estimate the results of } \\
\text { multi-digit multiplication } \\
\text { problems and the extent to } \\
\text { which this ability improves } \\
\text { with practice. }\end{array}$ & $\begin{array}{l}\text { The results showed that together with increase } \\
\text { in speed and accuracy with practice, the } \\
\text { participants also changed the strategies they } \\
\text { used. } \\
\text { The strategy analysis revealed that with } \\
\text { practice, the participants reduced their use of } \\
\text { the approximated calculations strategy, which } \\
\text { involves multiplying the rounded operands and } \\
\text { comparing the product to the reference } \\
\text { number, and increased their reliance on the } \\
\text { sense of magnitude strategy which does not } \\
\text { involve any calculation but grounded in the ANS. }\end{array}$ \\
\hline $\begin{array}{l}\text { Abreu-Mendoza } \\
\& \quad \text { Arias-Trejo } \\
(2015)\end{array}$ & $\begin{array}{l}\text { This study investigated the } \\
\text { abilities of individuals with } \\
\text { Down syndrome to } \\
\text { compare area and number, } \\
\text { and to compare them with }\end{array}$ & $\begin{array}{l}\text { The results showed that in general, the } \\
\text { performance of the three groups was better in } \\
\text { the Area comparison task than in the Number } \\
\text { comparison task. Critically, performance of } \\
\text { individuals with Down syndrome in both tasks }\end{array}$ \\
\hline
\end{tabular}




\begin{tabular}{|c|c|c|}
\hline & $\begin{array}{l}\text { those of the two control } \\
\text { groups of typically } \\
\text { developing individuals. }\end{array}$ & $\begin{array}{l}\text { was consistent with that of individuals (normal } \\
\text { individuals) with the same Mental age. The } \\
\text { study shows that the abilities to compare area } \\
\text { and numerosity are both preserved in } \\
\text { individuals with Down syndrome, and that these } \\
\text { individuals just like typically developing } \\
\text { individuals, show better performance in } \\
\text { comparing area than number. }\end{array}$ \\
\hline $\begin{array}{l}\text { Ziegler \& Stern } \\
(2014)\end{array}$ & $\begin{array}{l}\text { Year } 6 \text { Students studying } \\
\text { algebra often make } \\
\text { mistakes because of } \\
\text { superficial similarities } \\
\text { between addition and } \\
\text { multiplication problems. } \\
\text { To investigate whether } \\
\text { these errors can be } \\
\text { prevented by presenting } \\
\text { addition and multiplication } \\
\text { problems in such a way } \\
\text { that students are } \\
\text { encouraged to compare } \\
\text { the problems at a deeper } \\
\text { level. }\end{array}$ & $\begin{array}{l}\text { The finding in Experiment } 1 \text { at first showed that } \\
\text { the students performed worse under the } \\
\text { contrast condition. However, in the follow-up } \\
\text { tests, these findings were reversed where the } \\
\text { contrast group clearly outperformed the } \\
\text { sequential group. } \\
\text { The findings were replicated under improved } \\
\text { methodological conditions in Experiment } 2 . \\
\text { These experiments showed that comparisons } \\
\text { of superficially similar but conceptually } \\
\text { different learning materials result in improved } \\
\text { long-term learning. } \\
\text { Students often have considerable difficulties in } \\
\text { distinguishing between concepts because they } \\
\text { are usually introduced consecutively. To help } \\
\text { the learner distinguish between different } \\
\text { concepts and strategies, the research had } \\
\text { successfully introduced different concepts } \\
\text { simultaneously by contrasting them. }\end{array}$ \\
\hline $\begin{array}{l}\text { Abreu- } \\
\text { Mendoza, Soto- } \\
\text { Alba \& Arias- } \\
\text { Trejo (2013) }\end{array}$ & $\begin{array}{l}\text { To explore how the usage } \\
\text { of different visual controls } \\
\text { (density, total filled area, } \\
\text { and correlated and anti- } \\
\text { correlated areas) affect } \\
\text { children's performance in a } \\
\text { number of comparison } \\
\text { tasks, and its relationship } \\
\text { to children's cardinality } \\
\text { knowledge. }\end{array}$ & $\begin{array}{l}\text { The results showed that overall, children } \\
\text { performed above average in the number } \\
\text { comparison task; nonetheless, density was the } \\
\text { easiest control, while the correlated and anti- } \\
\text { correlated areas were the most difficult in most } \\
\text { cases. }\end{array}$ \\
\hline $\begin{array}{l}\text { Sasanguie } \quad \& \\
\text { Reynvoet } \\
2013)\end{array}$ & $\begin{array}{l}\text { To examine the relation } \\
\text { between the } \\
\text { linear/logarithmic fit in a } \\
\text { non-symbolic }\end{array}$ & $\begin{array}{l}\text { In two experiments, a correlation between the } \\
\text { estimation pattern in number line estimation } \\
\text { and the size effect in comparison was absent. } \\
\text { An ANOVA showed no difference between the }\end{array}$ \\
\hline
\end{tabular}




\begin{tabular}{|c|c|c|}
\hline & $\begin{array}{l}\text { number line estimation } \\
\text { task and the size effect } \\
\text { (SE) in a non-symbolic } \\
\text { comparison task in first-, } \\
\text { second- and third graders. }\end{array}$ & $\begin{array}{l}\text { groups of children with a linear or a logarithmic } \\
\text { representation considering their size effect in } \\
\text { comparison. }\end{array}$ \\
\hline $\begin{array}{l}\text { Lemaire \& } \\
\text { Lecacheur } \\
\text { (2011) }\end{array}$ & $\begin{array}{l}\text { To investigate the best } \\
\text { strategy selected by third-, } \\
\text { fifth- and seventh graders } \\
\text { for estimating answers to } \\
\text { two-digit addition } \\
\text { problems. }\end{array}$ & $\begin{array}{l}\text { The findings showed that children's skill at both } \\
\text { strategy selection and execution improved with } \\
\text { age. }\end{array}$ \\
\hline Star et al. (2010) & $\begin{array}{l}\text { To evaluate the } \\
\text { effectiveness of } \\
\text { comparison on students' } \\
\text { learning of } \\
\text { Estimation; this study } \\
\text { compared learning from } \\
\text { comparing multiple } \\
\text { solutions (compare } \\
\text { condition) to learning from } \\
\text { studying individually } \\
\text { presented solutions } \\
\text { (sequential } \\
\text { condition). }\end{array}$ & $\begin{array}{l}\text { The findings provide evidence of increased } \\
\text { student flexibility and conceptual } \\
\text { knowledge as a result of comparison; in } \\
\text { addition, this study provides a nice example of } \\
\text { a concrete, easily implemented technique for } \\
\text { implementing comparison, via the side by } \\
\text { side presentation of examples. }\end{array}$ \\
\hline $\begin{array}{l}\text { De Smedt, } \\
\text { Verschaffel \& } \\
\text { Ghesquiere } \\
\text { 2009) }\end{array}$ & $\begin{array}{l}\text { To examine the } \\
\text { relationship between a } \\
\text { number comparison task } \\
\text { with mathematics } \\
\text { achievement among the } \\
\text { first grade students. }\end{array}$ & $\begin{array}{l}\text { The findings provided longitudinal evidence that } \\
\text { the size of the individual's distance effect and } \\
\text { calculated on the basis of reaction times in } \\
\text { number comparison task was predictively } \\
\text { related to mathematics achievement. } \\
\text { Regression analyses showed that this } \\
\text { association was independent of age, intellectual } \\
\text { ability, and speed of number identification. }\end{array}$ \\
\hline $\begin{array}{l}\text { Star \& Rittle- } \\
\text { Johnson (2009) }\end{array}$ & $\begin{array}{l}\text { To evaluate the benefits of } \\
\text { supporting comparison in a } \\
\text { classroom context for fifth } \\
\text { and sixth grade students } \\
\text { learning about } \\
\text { computation estimation. }\end{array}$ & $\begin{array}{l}\text { The findings showed that students who } \\
\text { compared were more flexible problem solvers } \\
\text { on a variety of measures. } \\
\text { It is concluded that comparison also supported } \\
\text { greater conceptual knowledge, but only for } \\
\text { students who already knew some estimation } \\
\text { strategies. }\end{array}$ \\
\hline
\end{tabular}


INTERNATIONAL JOURNAL OF ACADEMIC RESEARCH IN BUSINESS AND SOCIAL SCIENCES Vol. 9, No. 2, Feb, 2019, E-ISSN: $2222-6990$ ๑ 2019 HRMARS

\begin{tabular}{|c|c|c|}
\hline $\begin{array}{l}\text { Rittle-Johnson, } \\
\text { Star \& Durkin } \\
\text { (2009) }\end{array}$ & $\begin{array}{l}\text { To investigate } \\
\text { the importance of prior } \\
\text { knowledge in learning } \\
\text { from the comparison of } 7^{\text {th }} \\
\text { and } 8^{\text {th }} \text { grade students } \\
\text { who learned to solve } \\
\text { equations by comparing } \\
\text { different solution methods } \\
\text { to the same problem, } \\
\text { comparing the } \\
\text { different problem types } \\
\text { solved with the same } \\
\text { solution method, or } \\
\text { studying the examples } \\
\text { sequentially. }\end{array}$ & $\begin{array}{l}\text { The results demonstrated that the students } \\
\text { with prior knowledge became more flexible } \\
\text { and improved their understanding of the } \\
\text { procedure in learning from comparison. } \\
\text { Comparisons of similar solution methods } \\
\text { emphasize differences in the methods, which } \\
\text { help to distinguish between them. } \\
\text { In conclusion, for those with little prior } \\
\text { knowledge of solution methods, it is best to } \\
\text { delay comparisons of multiple solution } \\
\text { methods. Rather, students should become } \\
\text { familiar with at least one method, either } \\
\text { through sequential study of examples } \\
\text { illustrating the method or through } \\
\text { comparison of different problems solved with } \\
\text { the same solution method. }\end{array}$ \\
\hline Star et al. (2009) & $\begin{array}{l}\text { To investigate the role of } \\
\text { students' prior knowledge } \\
\text { of estimation strategies in } \\
\text { the effectiveness of } \\
\text { interventions designed to } \\
\text { promote strategy flexibility } \\
\text { across two recent studies. }\end{array}$ & $\begin{array}{l}\text { Results indicated that students' fluency with } \\
\text { estimation strategies had an impact on which } \\
\text { strategies they adopted through comparison } \\
\text { approach. Students who exhibited high fluency } \\
\text { at pre-test were more } \\
\text { likely to increase their use of estimation } \\
\text { strategies that led to more accurate estimates, } \\
\text { while students with less fluency adopted } \\
\text { strategies that were easiest to implement. }\end{array}$ \\
\hline $\begin{array}{l}\text { Clarke \& Roche } \\
\text { (2009) }\end{array}$ & $\begin{array}{l}\text { To compare the larger of } \\
\text { two fractions for eight pairs } \\
\text { mentally, giving reasons for } \\
\text { their choice among sixth } \\
\text { grade students. }\end{array}$ & $\begin{array}{l}\text { The findings show that the successful students } \\
\text { use benchmark (transitive) and residual thinking } \\
\text { to solve the problem. } \\
\text { It is concluded that students' fraction } \\
\text { comparison strategies act as a foundation for } \\
\text { robust understanding and possible pointers for } \\
\text { instruction especially for development of } \\
\text { proportional reasoning. }\end{array}$ \\
\hline
\end{tabular}

Based on the analysis, symbolic comparison was a robust and consistent predictor of future mathematics compare to non-symbolic comparison. The findings provide evidence of increased students flexibility and conceptual knowledge as a result of comparison.

\section{Conclusion}

The results from the analysis indicated that comparisons of numbers and comparisons of various solutions strategies are the most commonly adopted research themes in mathematical learning. Most studies focus on primary school students and all studies are done abroad. This 
proves that there is a significant gap in the comparison approach in mathematical learning in Malaysia.

The findings showed that students' conceptual knowledge, procedural knowledge, and procedural flexibility are related to the greater implementation of the intervention which, when used sufficiently, can improve long-term mathematics learning (Hattikudur, Sidney, Alibali, 2016, Tavakoli, 2016; Ziegler \& Stern, 2016). This study suggests that teachers may need additional support in preparing mathematics instruction using comparison approach and knowing the benefits of different types of comparison in mathematics learning may persuade and help them to decide what to compare and when to use comparison.

It is encouraging to report that using comparison approach as intervention in school settings may improve teachers' practice. In the analysis, the use of the comparison approach resulted in increased mathematic achievement compared to the use of sequential approach. To find out which types of comparison works best in mathematic learning, new research is needed in which the implementation of the interventions by the teacher plays an important role.

\section{Corresponding Author}

Ilda Salwani Binti Ameer Hamza,

Technology University Malaysia

Malaysia

Email: salwani.hamza@moe.gov.my

\section{References}

Abdul Rahman, M.N., Syed Zamri, S.N.A., \& Leong, K. E. (2018). Kajian Meta-Analisis Pengetahuan Guru Matematik Di Malaysia. Jurnal Kurikulum \& Pengajaran Asia Pasifik, 6(2), 11-22.

Abreu-Mendoza, R. A., \& Arias-Trejo, N. (2015). Numerical and Area Comparison Abilities in Down Syndrome. Research in Developmental Disabilities, 41-42, 58-65.

Abreu-Mendoza, R. A., Soto-Alba, E. E., \& Arias-Trejo, N. (2013). Area vs. Density: Influence of Visual Variables and Cardinality Knowledge in Early Number Comparison. Frontiers in Psychology, 4, Article ID 805.

Bingolbali, E. (2011). Multiple Solutions to Problems in Mathematics Teaching: Do Teachers

Really Value Them? Australian Journal of Teacher Education, 36(1).

http://dx.doi.org/10.14221/ajte.2011v36n1.2

Clarke, D.M., \& Roche, A. (2009). Students' Fraction Comparison Strategies as a Window into Robust Understanding and Possible Pointers for Instruction. Educational Studies in Mathematics, 72(1), 127-138.

Cohen, L., Manion, L., Morrison, K. (2011). Research Methods in Education (Seventh). Routledge.

De Smedt, B., Verschaffel, L., \& Ghesquiere, P. (2009). The Predictive Value of Numerical Magnitude Comparison for Individual Differences in Mathematics Achievement. Journal of Experimental Child Psychology, 103, 469-479.

Fazio, L. K., DeWolf, M., \& Siegler, R. S. (2015). Strategy Use and Strategy Choice in Fraction 
INTERNATIONAL JOURNAL OF ACADEMIC RESEARCH IN BUSINESS AND SOCIAL SCIENCES

Vol. 9, No. 2, Feb, 2019, E-ISSN: $2222-6990$ ๑ 2019 HRMARS

Magnitude Comparison. Journal of Experimental Psychology: Learning, Memory, and Cognition.

Ganor-Stern, D., \& Steinhorn, O. (2018). ADHD and Math - The Differential Effect on Calculation and Estimation. Acta Psychologica, 188, 55-64.

Ganor-Stern, D., \& Weiss, N. (2015). Tracking Practice Effects in Computation Estimation. Psychological Research, 80, 434-448.

Ganor-Stern, D. (2015). When You Don't Have to Be Exact: Investigating Computational Estimation Skills with A Comparison Task. Acta Psychologica, 154, 1-9.

Hattikudur, S., \& Alibali, M. W. (2010). Learning about the equal sign: Does comparing with inequality symbols help? Journal of Experimental Child Psychology, 107(1), 15-30. http://dx.doi.org/10.1016/j.jecp.2010.03.004

Hattikudur, S., Sidney, P. G., \& Alibali, M. W. (2016). Does Comparing Informal and Formal Procedures Promote Mathematics Learning? The Benefits of Bridging Depend on Attitudes Toward Mathematics. Journal of Problem Solving. 9(1), 13-27.

Lemaire, P., \& Lecacheur, M. (2011). Age-Related Changes in Children's Executive Functions and Strategy Selection: A Study in Computational Estimation. Cognitive Development, 26, 282-294.

Linsen, S., Verschaffel, L., Reynvoet, B., \& De Smedt, B. (2015). The Association Between Numerical Magnitude Processing and Mental Versus Algorithmic Multi-Digit Subtraction in Children. Learning and Instruction, 35, 42-50.

Rittle-Johnson, B., Star, J. R., \& Durkin, K. (2009). The Importance of Prior Knowledge When Comparing Examples: Influences on Conceptual and Procedural Knowledge of Equation Solving. Journal of Educational Psychology, 101(4), 836-852. doi:10.1037/a0016026

Richland, L.E., Stigler, J. W., \& Holyoak, K. J. (2012). Teaching the Conceptual Structure of Mathematics. Educational Psychologist. 47(3), 189-203.

Sasanguie, D., \& Reynvoet, B. (2013). Number Comparison and Number Line Estimation Rely on Different Mechanisms. Psychologica Belgica, 53(4), 17-35. http://dx.doi.org/10.5334/pb-53-4-17

Star, J. R., Rittle-Johnson, B., \& Durkin, K. (2016). Comparison and Explanation of Multiple Strategies: One Example of a Small Step Forward for Improving Mathematics Education. Policy Insights from the Behavioral and Brain Sciences, 3 (2), 151-159. doi:10.1177/2372732216655543.

Star, J. R., Kenyon, M., Joiner, R., \& Rittle-Johnson, B. (2010). Comparison helps students learn to be better estimators. Teaching Children Mathematics, 16(9), 557-563.

Star, J. R., \& Rittle-Johnson, B. (2009). It pays to compare: An experimental study on computational estimation. Journal of Experimental Child Psychology, 101, 408-426. doi: 10.1016/j.jecp.2008.11.004

Star, J. R., Rittle-Johnson, B., Lynch, K., \& Perova, N. (2009). The role of prior knowledge and comparison in the development of strategy flexibility: The case of computational estimation. ZDM - The International Journal on Mathematics Education, 41, no. 5: 569-579.

Tavakoli, H. M. (2016). The Relationship Between Accuracy of Numerical Magnitude Comparisons and Children's Arithmetic Ability: A Study in Iranian Primary School Children. Europe's Journal of Psychology, 12(4), 567-583. doi:10.5964/ejop. v12i4.1175 
Webster, J., \& Watson, R. T. (2002). Analyzing the Past to Prepare for the Future: Writing a Literature Review. MIS Quarterly, 26(2), xiii-xxiii. http://doi.org/10.1.104.6570

Xenidou-Dervou, I., Molenaar, D., Ansari, D., van der Schoot, M., \& van Lieshout, E. C. D. M. (2017). Nonsymbolic and Symbolic Magnitude Comparison Skills as Longitudinal Predictors of Mathematical Achievement. Learning and Instruction, 50, 1-13. DOI: 10.1016/j.learninstruc.2016.11.001

Ziegler, E., \& Stern, E. (2016). Consistent advantages of contrasted comparisons: Algebra learning under direct instruction. Learning and Instruction, 41, 31-51.

Ziegler, E., \& Stern, E. (2014). Delayed benefits of learning elementary algebraic transformations through contrasted comparisons. Learning and Instruction, 33, 131-146. http://dx.doi.org/10.1016/j.learninstruc.2014.04.006 